Southern Methodist University

SMU Scholar

Faculty Journal Articles and Book Chapters

Faculty Scholarship

2007

\title{
Back to the Future: Is Form-Based Code an Efficacious Tool for Shaping Modern Civic Life
}

Lolita Buckner Inniss

Southern Methodist University, Dedman School of Law

\section{Recommended Citation}

Lolita Buckner Inniss, Back to the Future: Is Form-Based Code an Efficacious Tool for Shaping Modern Civic Life, 11 U. Pa. J.L. \& Soc. Change 75 (2007)

This document is brought to you for free and open access by the Faculty Scholarship at SMU Scholar. It has been accepted for inclusion in Faculty Journal Articles and Book Chapters by an authorized administrator of SMU Scholar. For more information, please visit http://digitalrepository.smu.edu. 


\title{
BACK TO THE FUTURE: IS FORM-BASED CODE AN EFFICACIOUS TOOL FOR SHAPING MODERN CIVIC LIFE?
}

\author{
LOLITA BUCKNER INNISS ${ }^{*}$
}

\begin{abstract}
This article serves as a critique of the New Urbanism in general and of form-based code in particular as a tool of the New Urbanism. It may be true that form-based code offers more flexibility than traditional zoning schemes and thus may offer some respite from acknowledged ills such as social and racial divisions created by exclusionary zoning and other tools, and from the relative inutility of single or limited use districts. However, I will argue that these benefits are eclipsed by some of the problems of formbased code. Form-based code is frequently hailed as a "back to the future" approach to both urban and suburban living which will cure numerous ills such as the physical decay, racial segregation, and economic downturns that are endemic to many United States cities and towns, but it may not be an effective means of addressing the decline of civic life. This is first because form-based code, in advocating for norms to re-create the city of the past, seeks to implement by design what was essentially a spontaneous and self-generated form of social organization driven largely by economic concerns rather than social or political concerns. Next, Urbanism, which is purportedly at the heart of New Urbanist planning schemes such as form-based code, is itself a contested notion, subject to many alternate visions of the city of the past. As a result, the implementation of form-based code premised on New Urbanism may lead to an ersatz Urbanism. Finally, and perhaps most salient among the critiques I present, form-based code's reliance upon the "community" to
\end{abstract}

${ }^{*}$ A.B. Princeton University, J.D. University of California, Los Angeles; LLM Osgoode Hall Law School, York University; PhD Candidate, Osgoode Hall Law School, York University; Associate Professor, Cleveland Marshall College of Law, Cleveland State University. I thank Professor Marcilynn Burke of the University of Houston Law School, Professor Audrey McFarlane of the University of Baltimore School of Law and Professor Guadalupe Luna of Northern Illinois University Law School for their insightful comments on an earlier draft. I offer special thanks to Professor and Dean Emeritus Harry Arthurs of Osgoode Hall Law School, York University for engaging me in the penetrating discussions which first inspired and later helped to shape this paper. Finally, I thank Teirra Everette for her research assistance and Venita Wiggins for her secretarial help. 
formulate design standards through the charrette process has the potential to further isolate those who are already disadvantaged.

\section{INTRODUCTION}

Since the 1980s, the notion of "New Urbanism" has taken hold as a theory for designing and redesigning towns and cities in the United States and elsewhere. New Urbanism argues for a return to the "traditional" pattern of cities, one that is characterized by mixed uses in densely populated, pedestrian friendly neighborhoods which offer easy access to workplaces, shopping, and recreation and maintain a fixed and widely shared aesthetic sensibility. ${ }^{1}$

This eclectic intermingling, it is argued, results in both economic and social vitality. The New Urbanism grows from Urbanism, a movement first seen in the 1920s and 1930s, which promoted human settlement in dense urban residential and commercial spaces as opposed to rural, suburban, or exurban areas. ${ }^{2}$ Proponents of New Urbanism believe that the implementation of Euclidean zoning schemes displaced the vital mix that defined the cities of old. ${ }^{3}$ New Urbanists assert that the vital mix never existed for newer towns founded purely on Euclidean principles of separation of use, and thus, such places exist as soulless shells. ${ }^{4}$ The New Urbanist remedy for this municipal malaise is to put into place the elements deemed crucial for maintaining a thriving civic life. ${ }^{5}$ Form-based code is

1 For a discussion of some of the explicit goals of New Urbanism, see RUTHERFORD H. PLATT, LAND USE AND SOCIETY: GEOGRAPHY, LAW, AND PUBLIC POLICY 273-274 (2004).

2 See, e.g., Lewis MuMford, The CITY IN History: ITS ORIGINS, ITS TRANSFORM 4 TIONS, AND ITS PROSPECTS 2-10 (1968 Harvest Books) (1961). In his book, Mumford seeks to return to the beginnings of the city and calls for an "organic" city in which technological innovation should not take precedence over the essential humanness of civilization: "...[w]e need a new image of order, which shall include the organic and personal, and eventually embrace all the offices and functions of man." $I d$. at 4.

3 Euclidean zoning refers to the segregation of land uses into specified geographic districts and dimensional standards. This form of zoning was upheld by the United States Supreme Court in Village of Euclid v. Ambler Realty Co., 272 U.S. 365 (1926). See infra note 49.

${ }^{4}$ Jane JaCobs, The, DeATH AND Life, of Great American Citifs 7 (1961). Jacobs, in referring to attempts at urbanization, writes of the "freshly-minted decadence of the new unurban urbanization." $I d$. Such modern municipalities are further exemplified by monotony, sterility, and vulgarity. $I d$.

${ }^{5}$ See, e.g., Patsy HFai,ey, The, Communicative. Turn in Pi.anning Theory AND I'TS IMPLICATIONS FOR SPATIAL STRA'TEGY FORMATION, in READINGS IN PLANNING 
one recently developed mechanism for achieving the goals of New Urbanism. ${ }^{6}$

Form-based code, known in its various incarnations as design-based zoning, community-based urban design, context-based design, smart growth code, or communicative action-based planning, ${ }^{7}$ is a land use regulatory and planning tool which is increasingly used to achieve the goals of New Urbanism in municipalities of various types, sizes, and locales. ${ }^{8}$ New Urbanism is founded on a core of Urbanism. Urbanism offered a distinct body of mechanisms for normative ordering in the civic environment, which, in its earliest incarnations, was not connected to government. ${ }^{9}$ Instead, the cities of old often spontaneously developed, with the buildings, streets, and neighborhoods themselves forming a type of "law." Because creating the amenities necessary to implement New Urbanism often requires substantial changes to infrastructure, form-based code is more frequently utilized in the design of new towns and undeveloped sections of towns and cities, or in efforts to infill or retrofit land in existing urban areas. Unlike the Euclidean zoning codes that are at the base of most zoning and planning schemes in United States cities and towns, ${ }^{1}$ form-based code focuses not on land use but on the character of

THEORY 237 (Scott Campbell ed., 2002) (discussing how "public argumentation and communicative policy practice" might address the interpersonal "fragmentation" that has occurred in modern cities).

${ }_{7}^{6} I d$.

${ }^{7} I d$.

${ }^{8}$ Some cities and towns that have recently adopted aspects of form-based code as part of the zoning process include Syracuse, New York; Palo Alto, California; Arlington, Virginia; Petaluma, California; Huntersville, North Carolina; Louisville, Kentucky; and Emmaus, Pennsylvania. Many more are either considering adopting form-based codes or in the process of drafting such codes. See e.g. Jason Miller, Smart Codes, Smart Places, ON COMMON GROUND (Summer 2004) available at http:/www.realtor.org/smart_growth.nsf/docfiles/summer04sm.pdf/\$FILE/summer04sm. pdf (presenting cases studies of towns exploring implementation of form-based codes).

${ }^{9}$ Sally Falk Moore, Legal Systems of the World: An Introductory Guide to Classifications, Typological Interpretations and Bibliographical Resources, in LAW AND THL SOCIAL SCILNCLS 11,15 (Leon Lipson \& Stanton Wheeler eds., 1986) (examining ways in which law and systems of maintaining order may not "have their source in government").

${ }^{10}$ According to Jacobs, the diversity was generated by the existence of certain design features which in effect generate "law"-the street, the neighborhood, the district, and ultimately the city are organs of self-government in the successful city. J $\Lambda$ COBS, supra note 4 at $117-122$.

${ }^{11}$ Some municipalities implement performance zoning instead of or in addition to Euclidean zoning. Frederick W. Acker, Note, Performance Zoning, 67 NOI'RE DAME L. 
development. Instead of attempting to segregate uses across neighborhoods or entire towns, form-based codes look to the scale, shape, scope and specific details of a particular development project.

Also unlike Euclidean zoning codes, form-based codes are most often prescriptive rather than proscriptive or descriptive. Hence, formbased codes tell developers what they can and should build in fine detail rather than telling them what they cannot build or describing generally permitted uses. Because of the level of detail in such codes and the potential curtailment of rights that such codes may mean for property owners, a crucial aspect of the adoption of form-based code is community involvement. This involvement is carried out via the "charrette" process, a series of meetings at which community members and other interested parties are invited to voice their desires for a particular type of project. $^{12}$

REV. 363, 364 (1991). Performance zoning employs performance-based or goal-oriented criteria to establish review parameters for proposed development projects in any area of a municipality, such as how a particular project impacts adjacent lands and public facilities. $I d$. at 369 . In its most unadulterated form, performance zoning allows for the broadest range of uses and creates a uniform system of performance standards throughout a particular municipality. Id. Other municipalities include incentive-based zoning as a supplement to Euclidean zoning. See Jerold S. Kayden, Market-Based Regulatory Approaches: A Comparative Discussion Of Environmental And Land Use Techniques In The United States, 19 B.C. ENVTL. AFF. L. REV. 565, 568-569 (1992). Incentive zoning, a close relative of performance zoning, offers zoning incentives to developers on the condition that specific physical, social, or cultural benefits are provided to the community. Id.

${ }^{12}$ Charrette (sometimes spelled "charette") is an architectural term that refers to a collective workshop process undertaken by designers and planners to reach consensus on the design of a particular project and to sketch out the project's preliminary form. See The National Charrette Institute, What Is a Charrette?, http://www.charretteinstitute.org/charrette.html (last visited November 26, 2007). The charrette has been increasingly used to encourage participation in urban development schemes and has been, states on commentator, a very deliberate part of the federal government's decentralization scheme in federally sponsored urban development. Audrey G. McFarlane, When Inclusion Leads to Exclusion: The Uncharted Terrain of Community Participation in Economic Development, 66 BROOK. L. REV. 861, 863 (2000). In the context of form-based code, the charrette usually involves lay members of a community interested in or affected by a project as well as design and planning professionals. Benjamin E. Northrup \& Benjamin J. Bruxvoort Lipscomb, Country and City: The Common Vision of Agrarians and New Urbanists, in THE ESSENTIAL. Agrarian ReAder: The Future OF Culture, COMMUNITY, AND THE LAND 191, 198199 (Norman Wirzba ed., 2004). It is said to have been conceived in the development of Seaside, Florida, one of the first acknowledged New Urban communities. Id. For a general discussion of the charrette in form-based code processes see Sim Van der Ryn and Rob Peña, Ecologic Analogues and Architecture, Consiruclion Ecology 231 , 
This article serves as a critique of the New Urbanism in general and of form-based code in particular as a tool of the New Urbanism. It may be true that form-based code offers more flexibility than traditional zoning schemes and thus may offer some respite from acknowledged ills such as social and racial divisions created by exclusionary zoning and other tools, and from the relative inutility of single or limited use districts. However, I will argue that these benefits are eclipsed by some of the problems of formbased code. Form-based code is frequently hailed as a "back to the future" approach that will cure numerous ills such as the physical decay, racial segregation, and economic downturns endemic to many United States cities and towns. Yet, it may not be an effective means of addressing the decline of civic life. I identify three reasons for this.

First, form-based code, in advocating for norms to re-create the city of the past, seeks to implement by design what was essentially a spontaneous and self-generated form of social organization driven largely by economic rather than social or political concerns. Next, Urbanism, which is purportedly at the heart of New Urbanist planning schemes such as form-based code, is itself a contested notion, subject to many alternate visions of the city of the past. As a result, the implementation of formbased code premised on New Urbanism may lead to an ersatz Urbanism. Finally, and perhaps most salient among the critiques I present, form-based code's reliance upon the "community" to formulate design standards through the charrette process has the potential to further isolate those who are already disadvantaged. While form- based code is not intended as a tool to advance political interests in and of itself, in the context of urban planning the charrette may easily be transformed into a mechanism of "responsibilitization"- the politically inspired move away from formal systems and the thrust of autonomy on those who previously lacked such autonomy. This may result in further isolating the most disadvantaged residents of towns and cities.

In order to illustrate the critiques I raise, I first briefly consider the historic evolution from traditional land use planning schemes to zoning, planning, and form-based code systems, and discuss some of the reasons for this evolution. Next, I will discuss form-based code and the communal

238-239 (Charles J. Kibert et al. eds., 2002); KenNeth Hal. \& Gerald PORTERfiei.d,

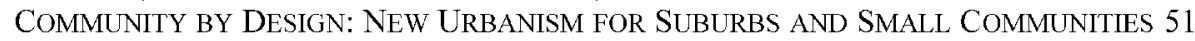
(2000). See also TiIOM DANiEls \& DeborAit Bowers, Holdng OUR Ground: PROTECTING AMERICA'S FARMS AND FARMLAND 40 (1997) (discussing the charrette as a way to enhance community participation in creating comprehensive plans and zoning ordinances). 
charrette process which is central to it. Finally, I illustrate my critique of communal planning with reference to a recent paradigm: the attempt to implement form-based code principles in the rebuilding of New Orleans in the aftermath of Hurricane Katrina.

\section{The Antecedents of United States Zoning And Urban Planning AND THE RISE OF FORM-BASED CODE}

Traditional zoning schemes are land use regulatory tools which typically prescribe designated land uses within a community with an ultimate goal of restraining density and separating primary uses. ${ }^{13}$ Zoning is one of several legal devices for implementing the proposals and objectives for land development as outlined in a city's comprehensive plan, which is its statement of the city's goals, objectives, principles, guidelines, policies, standards, and strategies for the growth and development of the community. Notwithstanding its ubiquity as a tool of planners, zoning is, within the scope of Anglo-American law and urban planning theory, relatively new, having been first articulated near the end of the nineteenth century. ${ }^{14}$ Well before zoning arose as a planning tool, American cities were developed in response to market rather than social forces, and mechanisms for development were typically found in private law solutions. Zoning followed these private land use arrangements, and in the late twentieth century, with the bloom well off the rose of zoning, there arose New Urbanist devices such as form based code.

\section{A. The Economic Impetus of City Formation}

Until the late nineteenth century, much of the population of the United States lived outside of the cities in relatively low density rural areas. Only five United States cities, New York, Philadelphia, Baltimore, Boston, and Charleston, had populations over 20,000 and these cities developed

${ }^{13}$ For a general discussion of the roots of planning, see JON A. PETERSON, TIIE BiRTH OF CITY PLANNING IN THE UNITED STATES, 1840-1917, at 1-28 (2003).

${ }^{14}$ Alexander von Hoffman \& John Felkner, The Historical Origins and Causes of Urban Decentralization in the United States, W02-1 HARVARD UNIVERSITY JOINT CENTER FOR HOUSING STUDIES 3 (2002), available at http://www.jchs.harvard.edu/publications/communitydevelopment/von_hoffman_w021.pdf (examining "physical patterns of urban development" in the nineteenth century within a study tracing the history of urban and suburban sprawl). 
around ports that supported commerce. ${ }^{15}$ Most of the persons living in early American cities were associated with the manufacture, marketing, and distribution of goods, which were the raisons d'être of the cities. ${ }^{16}$ As one commentator has observed, urbanization was structured around an ideological and cultural paradigm called "privatism," which focused on the accretion of individual wealth. ${ }^{17}$ United States cities were created, organized, and to a great extent defined, not as communities of social or political participation, but as a "fusion of money-making, accumulating citizens." 18 This meant that much of the land in urban and near-urban areas in the United States was owned or controlled by either an "old money" elite or by wealthy tradesmen and shopkeepers. ${ }^{19}$ These persons occupied the most usable, desirable, and ultimately most expensive land at the center of cities. $^{20}$ Poorer persons who managed to live in the city occupied side alleys and less desirable lowlands or thoroughfares at the sufferance of the wealthy. ${ }^{21}$ Because making improvements to the built environment was often considered a private concern, the poor had little voice in the development of the cityscape and received few of the benefits of such development. $^{22}$ For example, in much of nineteenth century Chicago, physical improvements were the responsibility of individual property owners, and thus landless citizens were often without amenities such as sidewalks and sewers. ${ }^{23}$ Development was not governed by fixed, clearly articulated standards, but rather by ad hoc arrangements generated by private negotiation among land owners.

\section{B. Private Land Use Agreements as Planning Devices}

${ }^{15} I d$.

${ }^{16} \mathrm{Id}$. at 3-4.

17 Timothy J. Gilfoyle, Urbanization, in A COMPANION TO 19TH-CENTURY AMERICA 152, 156 (William L. Barney ed., 2001) (describing the work of Sam Bass Warner, Jr. which traces the growth of urban communities to the cumulative efforts of individual business interests, rather than to a collective "public or political" process).

${ }^{18} \mathrm{Id}$.

${ }^{19} \mathrm{Id}$.

${ }^{20}$ See Priscilla Ferguson Clement, Welfare $\Lambda$ ND tite PoOr in tiIE 19Ti Century City: Philadelphia 1800 to 1854 , at 24-25 (1985) (depicting the development of Philadelphia and the distribution of its population by class between the city's center and the outer districts).

\footnotetext{
${ }^{21} \mathrm{Id}$.

${ }^{22}$ GILFOYLE, supra note 17 at 156 .

${ }^{23} \mathrm{Id}$.
} 
Members of the urban land owning classes frequently relied in the first instance upon the implicit understandings of their class regarding land use standards. ${ }^{24}$ If these informal agreements failed, they also had access to the formal legal tools that had long been a part of Anglo-American jurisprudence: express private agreements and nuisance law to police land use. Private land use agreements typically contained proscriptions on actions related to land or placed affirmative duties upon the parties in relation to their control or ownership of land, and usually took the form of easements or covenants which could be invoked in the event of a breach. ${ }^{25}$ Nuisance law generally allowed persons to address harmful actions by neighbors or others which were not covered by pre-existing agreements. ${ }^{26}$ These traditional land use control mechanisms had significant limits, however, which became all too obvious in the dawn of the twentieth century.

First, private land use agreements were not always in place before a problem arose and hence could not be called upon to resolve such problems. Next, even though resort to nuisance law required no prior agreement between the parties, there were some land uses which, while objectionable to others, did not meet the traditional high standard for nuisance; courts sometimes refused to prohibit potentially objectionable land uses in the interests of fostering development. ${ }^{27}$ A nuisance occurs when one landowner uses her land so as to unreasonably interfere with another landowner's use and enjoyment of her land. ${ }^{28}$ The key is reasonableness, which varies from case to case and is highly fact-specific. Uses that merely offend the aesthetic sensibilities of one party are not necessarily nuisances, a limitation which often substantially reduced the potency of the nuisance doctrine. This was of particular concern to the traditional landed classes since, in the period near the turn of the nineteenth

${ }^{24} I d$.

${ }^{25}$ Michael D. Bayles, Principles of LaW: A Normative ANAlysis 111-113 (1987).

${ }^{26}$ William J. Novak, Tite PEOPle's Welfare: LAW and REgulation in NINETEENTH CENTURY AMERICA 61-62 (1996) (characterizing nineteenth century nuisance law as a "jurisprudential framework" with the capacity to shape a broad range of commercial and private activities); see also B AYLES, supra note 25 at 235-236.

${ }^{27}$ See e.g., JESSE DuKEMINIER \& JAMES E. KRIER, PROPERTY $951-952$ (2002) citing Elmer S. Forbes, Rural and Suburban Housing, in PROCEEDINGS OF THE SECOND NATIONAL CONFERENCE ON HOUSING (1912) (discussing the harms caused by the locating of Chinese laundries, garages, and other unpleasantries near the expensive homes of wealthy landowners, the latter of whom were left without legal redress).

${ }^{28}$ BAYI.FS, supra note 25 at 235-236. 
century, many social codes that often kept the urban poor and working classes well away from the rich were broken. As a result, some wealthy landowners were confronted with behaviors by nearby landowners that, while possibly annoying or even offensive to certain personal or community norms, were not actionable.

Second, in the large cities with industrial or commercial concerns in close proximity to carriage trade or exclusive residential areas, incidental through traffic was sometimes a source of annoyance. For example, merchants on New York's Fifth Avenue decried the possibility that the immigrant masses employed in nearby businesses could walk on the streets at lunchtime, destroying the exclusive character of their businesses, and in the view of the merchants, reducing property values. ${ }^{29}$ Nuisance law could offer no remedy for such problems. In addition, because nuisance law provides a post hoc remedy and can only be invoked after a problem arises, and because it is highly fact specific, it was difficult for landowners to predict when or if their own actions would be the subject of nuisance claims. ${ }^{30}$ Landowners who sought to put their land to new or different uses faced the possibility that the projects in which they invested could be halted by the application of nuisance law.

Finally, by the early twentieth century, notions of social exclusivity, the permanence of social class, and the concentration and retention of wealth in a relative few gave way, if not factually then ideologically, to broad notions of equality in both social and legal relations. ${ }^{31}$ This was especially true as it concerned land ownership and use. The fixed but invisible geographic boundaries and land use norms that had for generations divided rich from poor and immigrant strivers from wealthy merchants were quickly dissolving in the stew of modern urban life.

Limits to traditional law, combined with the widespread socioeconomic transformation seen at the beginning of the twentieth century meant that a new mechanism was required to control land use. This

${ }^{29}$ Peter Hall, Cities of TOMORrow 61 (2002) (chronicling the role of commercial interests in the passage of New York City's pivotal 1916 zoning ordinance).

${ }^{30}$ DUKLMINILR, supra note 27 at 952 (describing the uncertain financial risk that nuisance law might contribute to a business venture).

${ }^{31}$ This transition from status bound relations to greater personal legal autonomy for the individual is perhaps most famously summed up by English jurist Henry Sumner Maine who in 1861 described this process as the move from status to contract. JOHN R. SUTTON, LAw/SOCIETY: ORIGINS, INTERACTIONS, AND CIIANGE 26-31 (2001). Sutton also reflects upon the work of Emile Durkheim, Auguste Comte, Ferdinand Tonnies, and other middle and late nineteenth century social and legal theorists who considered the effects of urbanization and modernization on social and legal relations. Id. at 31-34. 
new mechanism was zoning. New York is generally said to have passed the first city wide zoning code, adopted in $1916 .^{32}$ A number of cities soon followed suit, and much of the zoning enabling legislation originally adopted prior to 1924 was based on the New York general city enabling act. $^{33}$

\section{The Rise of Zoning Codes}

Zoning codes were in many cases meant to counter the ills of the urban environment in the United States which arose from the Second Industrial Revolution, dating from roughly 1850 until the beginning of the nineteenth century. ${ }^{34}$ This period was heralded by unprecedented innovation, technological advances, and notions of limitless abundance. ${ }^{35}$ It was also characterized by previously unseen levels of pollution and other environmental degradation. ${ }^{36}$ This was, moreover, a time of seismic socioeconomic change, vastly altered mores, and an associated anomie, all of which caused the period to be described by various commentators as both the beginning of, and the beginning of the end of, the "American" way of life. ${ }^{37}$ This vast schism in the perceptions of early twentieth century life grew largely from the social mobility that accompanied the changes of this

32 J. Barky Cullingworth, The POlitical Culture of PlanNing: AMERICAN LAND USE PlanNING IN COMPARATIVE PERSPECTIVE 26 (1993) (chronicling the passage of a city-wide ordinance that included districting provisions to dictate new land uses).

${ }^{33} I d$. at 27.

34 See e.g. Stephanie B. Kelly, Community Planning: How To Solve URBAN Environmental Problems 68 (2004) (recognizing the role of safety concerns in the passage of zoning ordinances in Great Britain in the late nineteenth century, and in New York in 1916); see also Paul Wheeler, An Architectural Perspective on the Future of the Workplace, in BuILding THE KNOWLEDGE ECONOMY: IsSuES, APPLICATIONS, CASE STUdIES 1131 (Paul Cunningham et al. eds., 2003) (examining the arrangement of the urban environment into working and living spaces, as an "enduring legacy of the industrial revolution").

35 ThOMAS C. Shlvory, Body/Politics: Siudiss in Rlproduction, PRODUCTION, $\Lambda$ ND (RE)CONSTRUCTION 24 (2000).

${ }^{36}$ KELLY, supra at note 34.

${ }^{37}$ Barry W. Johnson \& Martha Briton Eller, Federal Taxation of Inheritance and Wealth Transfers, in INHERITANCE AND WEALTH IN AMERICA 61, 66-67 (Robert Keith Miller \& Stephen J. MeNamee eds., 1998) (discussing social and economic shifts that resulted from industrial growth and their influence on inheritance laws, including rural to urban migration and a shift in wealth concentration from real estate and agriculture to industry and the stock market). 
period. ${ }^{38}$ While social mobility was arguably one of the hallmarks of life in the United States because it resulted in a broadening of the middle class and the rise of a new wealthy class, it was also the bane of the established landed upper classes. Explicit, legislated urban planning was a means of mediating the burgeoning class conflict in American cities. ${ }^{39}$ Because some of the world's older cities had already begun to confront this challenge, many looked to Europe for answers and especially to the land use mechanism being developed in parts of England which came to be known as the Garden Cities movement.

The Garden Cities movement, developed by English social reformer Ebenezer Howard, is said to have served as the ideological roots of planning and ultimately of zoning. ${ }^{40}$ Howard developed his proposals to improve the lives of London inhabitants, advocating for a resettling of some of London's inhabitants into small, new towns in the countryside where they could avoid the harsh, crowded conditions of the large city. These new cities were characterized by an effusion of single family houses, surrounded by gardens. Howard's idea had several unique aspects. First, it called for a strict segregation of uses and a permanent belt of open land, which would limit the growth of the new city. ${ }^{41}$ It dispensed with private ownership and called for municipal ownership of the entire tract; land would be distributed via leasehold to inhabitants. ${ }^{42}$ The movement further called for limits on population and the development of industries able to support the population, and made provision for the founding of new communities as original garden cities became fully inhabited. ${ }^{43}$

A number affluent, influential, and socially conscious Americans helped to bring Howard's ideas to the attention of American city planners. Many of these the planners adopted some of Howard's ideas in their efforts to design the new city of the twentieth century. ${ }^{44}$ One result was the creation of the City Beautiful movement, premised on the notion that civic

${ }^{38} I d$.

${ }^{39} \mathrm{Id}$.

40 See generally EBENEZER Howard, GARDEN CITIES OF TOMORROW (F.J. Osborn ed., M.I.T. Press 1965; originally published in 1902 as GARDLN CITILS Ol TOMORROW; first published in 1898 as TOMORROW: A PEACEFUL PATII TO REAL REFORM).

${ }^{41}$ Lewis Mumford, Introduction to HOWARD, supra note 40 at 29, 34 (detailing Howard's "original" prescriptions for the development of the Garden City regarding urban growth and community relationships to urban and rural patterns).

${ }^{42} I d$. at 35

${ }^{43} I d$.

${ }^{44}$ PEI'LRSON, supra note 13 at 232. 
revitalization, and ultimately social progress, could be achieved by beautification and sanitation regimes with attention to landscape design, municipal improvement and civic configuration. ${ }^{45}$ The culmination of the City Beautiful movement coincided with the adoption of segregated uses and the preference for single family homes, the most noteworthy of Howard's ideas to be embraced by American civic planners. ${ }^{46}$ Starting in the late $1800 \mathrm{~s}$, inspired by Howard, and in response to concerns about building uniformity, public health, safety and welfare, cities and towns began to develop zoning codes. ${ }^{47}$ Zoning has been hailed as the single most important innovation promoted by American planners in the years prior to World War I. $^{48}$ In 1926, the United States Supreme Court established the legality of zoning in Village of Euclid v. Ambler Realty. ${ }^{49}$

In Euclid, Ambler Realty Company, owners of land in the village of Euclid, Ohio sought to enjoin the village from enforcing a comprehensive zoning ordinance. Euclid's zoning ordinance rendered one portion of Ambler's tract useable for only single or two family homes, another portion for single or two family homes and limited auxiliary uses, ${ }^{50}$ and a third portion open to a broad number of residential, commercial, and industrial uses. $^{51}$ Ambler alleged that it had held the land for a number of years for the purpose of developing it as industrial land, and that if put to industrial use the land would be four times more valuable than when zoned residential. ${ }^{52}$ Thus, Ambler argued, the zoning constituted an unconstitutional taking under the Fourteenth Amendment of the United States Constitution. ${ }^{53}$

At trial, the United States District Court for the Northern District of Ohio held that the ordinance was "unconstitutional and void, and enjoined

${ }^{45}$ William H. Wilson, The Ideology, Aesthetics and Politics of the City Beautiful Movement, in THE RISE OF MODERN URBAN PlannING, 1800-1914, at 165, 166 (Anthony Sutcliffe ed., 1980) (linking the City Beautiful movement to "the landscape design, municipal improvement, and civic design movements" of the late 1800s).

${ }^{46}$ Peterson, supra note 13 at 308.

${ }^{47}$ Id. at 308-309.

${ }^{48} I d$. at 308

49272 U.S. 365 (1926). For a broad discussion of the Euclid case and of Euclidean zoning in general, see Richard Chused, Symposium On The Seventy-Fifth Anniversary Of Village Of Euclid v. Ambler Realty Co.: Euclid's Historical Imagery, 51 CASE W. RES. L. RFV. 597 (2001).

${ }^{50} 272$ U.S. at 380-81 (permitting auxiliary uses including churches, schools, cultural, and recreational use).

${ }_{51} I d$.

${ }^{52} I d$. at $384-85$.

${ }^{53} \mathrm{Id}$. at 384 . 
its enforcement." 54 Euclid sought appellate review. The United States Supreme Court upheld the zoning based on the village's inherent police power. $^{55}$ While the Court found that the exact line between the legitimate and illegitimate use of the police power varied under different facts and circumstances, the Court nonetheless held that zoning based on more than the narrow prevention of common law nuisance is acceptable. ${ }^{56}$ The Court held that before a zoning ordinance can be declared unconstitutional, the challenged provision must be clearly arbitrary and unreasonable, having no substantial relationship to public health, safety, morals, or general welfare. $^{57}$ Euclid settled the constitutionality of comprehensive zoning. Since Euclid, zoning ordinances bear a presumption of validity. When they are subject to challenge, the provisions are reviewed under a rational basis standard. In the aftermath of Euclid, legislated land use by zoning quickly became the norm in cities and towns in the United States.

While zoning was not meant to supplant private land use arrangements, in many instances it did just that, offering broad, legislatively created standards which were often used in lieu of and not in addition to private land use arrangements. It was ostensibly a collectivist approach to the system of land use planning whereby some of the "sticks" in the famed "bundle of sticks" metaphor for property rights are transferred to a municipal entity for reallocation to the entire community. ${ }^{58}$ However, zoning represents contradictory norms and impulses; it embraces both communitarian and elitist principles. This is because zoning's preference for separation of uses, particularly separation of residential uses from commercial or industrial uses, and low density residential uses from high

${ }_{54}^{54}$ Id.
${ }^{55}$ Id. at 397.
${ }^{56}$ See 272 U.S. at $387-88$ (citing Cusack v. City of Chicago, 242 U.S. $525,529-$ 30 (1917)); Hadachek v. Sebastian, 239 U.S. 394 (1915) (upholding a municipal ordinance that shut-down a brick making operation in Los Angeles as a legitimate nuisance regulation); Reinman v. Little Rock, 237 U.S. 171 (1915) (upholding a municipal ordinance that excluded a livery stable from a residential area); Welch $v$. Swasey, 214 U.S. 91 (1909) (showing support for the municipal reliance on police power to prohibit uses which could cause nuisances).

${ }^{57} 272$ U.S. at 395.

${ }^{58}$ One observer describes zoning's effect on the common law bundle of sticks as being akin to a set of quivers that constrain the sticks. JOHN G. FRANCIS \& LFSI.IE Pickering Francis, Land Wars: The Politics of PROPERTy AND COMMUNITy 113 (2003). Yet another commentator conceived of the bundle as consisting of green sticks and red sticks, with green sticks representing rights, and red sticks signifying duties. Rutherford H. Platt, land Usf, and Socifty: Geggraphy, Law, and Pubicic POLICY 93-100 (1996). 
density uses, made it a versatile tool for enshrining race-based privilege and perpetuating disadvantage. ${ }^{59}$

Indeed, in the earliest days of zoning, communities often implemented blatantly racist zoning schemes, the first of which was a 1910 Baltimore, Maryland ordinance that zoned the city into blocks that were either all white or all black. ${ }^{60}$ A number of American cities followed suit. ${ }^{61}$ Although there were a number of challenges against this practice, these challenges met with mixed success. ${ }^{62}$ Finally, Buchanan v. Warley struck down the practice of explicit race-based zoning. ${ }^{63}$ In Buchanan, the United States Supreme Court held that a Louisville, Kentucky ordinance requiring residential segregation based on race violated the Fourteenth Amendment of the United States Constitution. Prior state court rulings had overturned racial zoning ordinances on takings clause grounds because these ordinances failed to exclude land owned prior to enactment. The Court in Buchanan ruled that the justification of the Louisville ordinance based on race was an insufficient purpose to make the law constitutional. ${ }^{64}$ In the aftermath of Buchanan, however, cities often sought to create legally defensible racial zoning ordinances. ${ }^{65}$

In recent decades, as obvious displays of racial bias have become not only illegal but also socially unacceptable, traditional zoning schemes have eschewed explicit racial references. Nonetheless, modern zoning schemes still frequently serve as tools of social exclusion. This is especially true when implemented in newer towns and suburbs where requirements such as minimum lot sizes have the effect of increasing the cost of housing so that it is beyond the means of lower-income households. ${ }^{66}$

${ }^{59}$ See JANE M. JACOBS \& RUTH FINCHER, CITIES OF DIFFERENCE 51 -52 (1998)

${ }^{60}$ See Christopher Silver, The Racial Origins of Zoning in American Cities, in Urban PlanNing and the African AMERICAN COMMUNity: In THE SHADOWs 23, 27 (June Manning Thomas \& Marsha Ritzdorf eds., 1997).

${ }^{61}$ Racial zoning was seen throughout the South in cities such as in Richmond, Virginia, and Atlanta, Georgia. It was also implemented in Northern cities such as Chicago, Illinois and in some California cities. Id. at 25-28.

${ }^{62}$ Some state court rulings overturned racial zoning ordinances on takings clause grounds due to those ordinances' failures to exclude land owned prior to enactment.

${ }^{63}$ Buchanan v. Warley, 245 U.S. 60 (1917).

${ }^{64} \mathrm{Id}$. at 82 .

${ }^{65}$ See Silver, supra note 60 at 32 (Describing the various types of racial zoning ordinances after Buchanan).

${ }^{66}$ For example, in S. Burlington County NAACP v. Mount Laurel Twp., 336 A.2d 713 (N.J. 1975) (hereinafter Mt. Laurel I), the New Jersey Supreme Court ruled that municipalities had a constitutional obligation to provide a "fair share" of low- and moderate-income housing. The decision responded to a variety of zoning practices in 
There has been a sea of change in the challenges facing the American city since the widespread adoption of zoning as the principal tool of city planners. First, in a number of older American cities in the Northeast and Midwest, depopulation rather than overcrowding is a significant problem. ${ }^{67}$ In many of America's oldest cities, thriving middleclass communities of the early and mid-twentieth century have given way to an ever-burgeoning group of have-nots. In an effort to diagnose and treat the malady of the declining American urban area, New Urbanist planners have increasingly turned to the pre-zoning city of the past as a model. Form-based code is one mechanism for this revitalization.

\section{Form-based Code as New Urbanist Tool}

Form-based code is part of a broader movement in planning theory which focuses on "communication, collaboration, mediation and diversity." ${ }^{68}$ Indeed, in recent years the use of words such as "radical"

rural and suburban communities that were designed to exclude affordable housing from these areas. The court found that exclusionary zoning went against the communities' obligations to provide for the welfare of not only the town but the general region. In $S$. Burlington County NAACP v. Mount Laurel Twp., 456 A.2d 390 (N.J. 1983), the New Jersey Supreme Court discussed the fact that municipalities were failing to address the sorts of exclusionary zoning practices which had been the basis of Mt. Laurel I. Hence, the New Jersey Supreme Court reaffirmed the principles of the earlier decision and required municipalities to implement a variety of "affirmative" governmental mechanisms. One of the most noteworthy aspects of the decision was the Court's provision of a "builder's remedy," which allowed builders or landowners who wanted to provide low- and moderate-income housing in a jurisdiction to sue a municipality to obtain approval notwithstanding existing zoning standards for an area.

${ }^{67}$ See M. CiIRISTine Boyer, Dreaming tie RATion $\lambda$ L City: Tile Mytil of AMERICAN CITY PLANNING 237 (1986). The "rust belt" phenomenon, the deindustrialization, decay and depopulation of older U.S. cities has been produced by a number of factors, among them the loss of manufacturing jobs and their partial replacement by knowledge-intensive white collar jobs often requiring post-secondary education. John D. Kasarda, Cities as Places Where People Live and Work: Urban Change and Neighborhood Distress, in INTERWOVEN DESTINIES: CITIES AND THE NATION 81, 83 (Henry Cisneros ed., 1993). This has meant that already-present poorly educated inner city residents were excluded from employment. $I d$. The decline of these Northeastern and Midwestern cities has, however, to a great extent been paralleled by the almost exponential growth of "sun belt" cities in the South and Southwest. Eli Ginzberg, The Changing Urban Scene: 1960-1990 and Beyond, in INTERWOVEN DESTINIES: CITIES $\Lambda$ ND TIIE N$\triangle T$ TION 31, 35-37 (Henry Cisneros ed., 1993).

${ }^{68}$ JOHN S. FriedmanN, THE ProspeCt OF CITIES 101 (2002).

${ }^{69}$ See, e.g., John S. Frifdmann, Pilanning in THF, Pubi,ic Domain: From KNOWLEDGE TO ACIION 412 (1987) (describing radical planning as having little in 
"insurgent" $" 70$ in association with planning schemes has signaled a fundamental alteration in the way that planning functions are carried out. Governmental authorities will no longer exercise an exclusive monopoly over the process; ${ }^{71}$ rather, the idea is to include a broad cross-section of the populace at the ground level. ${ }^{72}$ These ideas have been propagated by a number of planning experts. ${ }^{73}$ Though form-based code is seen in various iterations in U. S. municipalities, it is typified by the presence of most or all of the following fixed characteristics: a controlling regulating plan, a framework of urban regulations, regulations defining streets and related passageways, landscape regulations, and finally, architectural regulations. ${ }^{74}$ Perhaps the most defining features of form-based code are its design-based rather than use-based standard for development and its reliance on the community in conjunction with city officials and planning professionals to articulate the nature of the design. ${ }^{75}$ This means that the characteristics which define a form-based code regime are often presented as "empty boxes" to be filled at the discretion of the multiple actors involved in reaching consensus. Form-based code, with its attention to detail on the most local level, appears to be the ultimate tool of the New Urbanism movement. New Urbanism, however, is a movement which is itself subject to critique because of its uncertain foundations and unsubstantiated claims.

New Urbanism, while seemingly a single strand of American planning founded upon assertions about the nature and scope of "traditional" American Urbanism, is actually a compilation of multiple viewpoints and approaches to civic planning. ${ }^{76}$ New Urbanism represents

common with policy analysis or social reform, but rather having more to do with the recovery of political community).

${ }^{70}$ See LeONIE SANDERCOCK, COSMOPOLIS II: MONGREL CITIES IN TIIE TwENTYFIRST CENTURY 47 (2003) (stressing the importance of the struggles between space and place with planning policies).

${ }^{71}$ See FrIEDMANN, supra note 68 at 101 (arguing how recently there has been an increased focus on involving civil society in plan-making).

${ }^{72} \mathrm{Id}$.

${ }^{73}$ See, e.g., SANDERCOCK, supra note 70 at 47 (recognizing that the future multicultural city must acknowledge the politics of difference).

${ }^{74}$ See Robert J. Sitkowski \& Brian W. Ohm, Formed Based Land Development Regulations, 38 URB. LAW. 163, 163-65 (2006) (enumerating and elaborating upon the defining characteristics of form-based code).

75 See Kenneth B. Hall Jr. \& Gerald A. Porterfield, Community by DESIGN: NEW URBANISM FOR SUBURBS $\Lambda$ ND SMALL COMMUNITIES 50-51 (2000) (laying out the process of the design phase in the community planning).

76 See Emit,y Talifn, New Urbanism and Amfrican Pianning: ThF CONFLICI OF CULTURES 4-5 (2005) (standing for and elaborating on the proposition that 
an effort to create a fuller and more nuanced framework for urban living. ${ }^{77}$ This has often meant calls for a return to the United States cities and towns of the pre-zoning nineteenth century, where, for example, much of the population lived in or around a defined center in densely built enclaves. Walking was one of the principal means of transportation, and most jobs were within city limits. These burgs, we are given to understand, were exemplary in both form and function. New Urbanism mediates for a return to this traditional way of living by implementing zoning and planning norms that will create or recreate such communities. Though sometimes known by other names such as Neotraditional Planning, Traditional Neighborhood Development, Transit-based Development, and even New Suburbanism, in every incarnation New Urbanism extols the virtues of the cities and towns of former times. ${ }^{78}$ There are, however, numerous critiques of Urbanism which have been launched in the years since the inception of the movement. ${ }^{79}$ Three of these critiques are particularly salient. First, it is not clear that there is a single type of traditional Urbanism. Next, traditional urban form was for the most part serendipitous, arising more in response to the economic needs, geographic positioning and demographic characteristics of the particular urban locale. Finally, it is not clear that the New Urbanist vision adequately addresses the way that people want to live now.

\section{Multiple Strands of Urbanism}

There is perhaps no single variety of "traditional" Urbanism back to which the New Urbanism may hearken. Urbanism has, according to one scholar, suffered a continual "crisis of definition." the broad concept of Urbanism described life in the city environment as opposed to suburban or rural life. But there the consensus ends. It has been argued that Urbanism, rather than being descriptive of one movement, is really an amalgam of multiple and sometimes competing "cultures." One of these cultures calls for attention to the built environment on a micro

new urbanism is actually a compilation of multiple viewpoints).

${ }^{77} \mathrm{Id}$.

78 See J. Barry Cullingworth \& Roger Caves, Planning IN the USA: POLICIFS, ISSUES, AND PROCFSSES 138 (2003). Urbanism).

79 See TALEN, supra note 76 at 3-5 (discussing the common critiques of

${ }^{80}$ TALEN, supra note 76 at 1.

81 See TAIFN, supra note 76 at 2 (describing the "connections and conflicts" between the various approaches to Urbanism in the United States as "cultures"). 
scale, focusing, for example, on particular recreational spaces or educational facilities. ${ }^{82}$ Another form of Urbanism looked to macrodevelopmental approaches for the creation and maintenance of the urban environment, with attention to broad land use norms or on large-scale local and regional transit systems. ${ }^{83}$ Some views on Urbanism have actually been exurban in view, looking to the areas beyond the city as the ultimate in desirable human habitats. ${ }^{84}$ Finally, some types of Urbanism have been more ecologically focused, and have looked to ways to reconcile the built environment with the natural environment. ${ }^{85}$

To recognize the existence of competing impulses ever-present in the Urbanism movement, which sometimes threatened to undermine the very reason for such a movement, one need only consider that the great names in urban planning, such as Ebenezer Howard, Frank Lloyd Wright, and Le Corbusier, were themselves staunchly opposed to the cities of their times. All three envisioned urban utopias that would constitute radical reconstructions of the city so as to eliminate features that they believed to be baneful, such as high density and mixed uses. ${ }^{86}$ Yet, these very features are now extolled as virtues of the "traditional" urban environment and the goal of most New Urbanist planning.

\section{Accidental Urbanism}

Even where specific notions of traditional Urbanism can be articulated as the basis of a distinct New Urbanism, it is important to recognize that regardless of form, traditional Urbanism, was, for the most part, accidental. The irony of New Urbanism is that it trades on the accidental developments of the past and attempts to make them manifest via an explicit, highly stylized planning scheme such as form-based code. With New Urbanism, as with some of the urban utopia movements of the late nineteenth and early twentieth centuries, the past is appropriated to legitimate the roots of what was and is a very new endeavor. New Urbanism seeks to rationalize a desire for that which was never necessarily

${ }^{82}$ See Id.
${ }^{83}$ See Id.
${ }^{84}$ See Id.
${ }^{85}$ See Id.
${ }^{86}$ See ROBERT FISIIMAN, URBAN UTOPIAS IN TIIE TWENTIETII CENTURY: Ebenezer Howard, Frank Lloyd Wright, Le Corbusier 3-4 (1982) (arguing that Ebenezer Howard, Frank Lloyd Wright, and Le Corbusier believed that their societies needed new kinds of cities). 
intended to exist in any particular form. ${ }^{87}$ So-called best practices in urban planning and urban living are often based on revisionist high points of the past which glide over flaws in order to sustain the myth of our ideal urban past. ${ }^{88}$ Perhaps most damning to the goal of reinstating the urban past is that it is none too clear that this represents the way that people in current cities want to live.

\section{New Urbanism and the Way We Want to Live}

The operative assumption, and one even born out by periodic polls conducted in various regions, is that the New Urbanism represents the way that Americans want to live. ${ }^{89}$ There is little proof, however, that the various constituencies of today's cities, suburban towns or larger, inner ring suburbs hanker for a particular New Urban vision or for any at all. As one scholar has written, the ideology of New Urbanism is both "utopian and deeply fraught." $" 90$ This is reflected in a rhetoric which assumes that the United States in general and its cities in particular are populated by likeminded persons who share a desire for "community" but who "have only the dimmest idea of what that means in terms of physical design." ${ }^{91}$ Though the New Urbanism movement pulls within its fold persons from varying social, economic, and racial backgrounds, it is none too clear that the "traditional" city that they all remember is the same one. "Wellfounded" communities, it has been pointed out, often exclude, frequently by defining themselves against others and ultimately serve as barriers to, rather than sources of, social change. ${ }^{92}$ Though rarely acknowledged, the

\footnotetext{
${ }^{87}$ Cf. RoBert FreEstone, Le $\Lambda$ RNING From PL $\Lambda$ NNING'S Histories, IN URBAN PlanNING IN A CHANGING WORLD: THE TWENTIETH CENTURY EXPERIENCE 1-2 (Robert Freestone ed., 2000).

${ }^{88}$ See $i d$. at 2 (standing for and elaborating on the proposition that best practices are based on the perceived high points of the past).

${ }^{89}$ See Peter Calthorpe \& William Fulton, The Regional City: New Urbanism \& the End of Sprawl 130 (2001) (demonstrating that Americans favor public gathering places, walkability, transit accessibility, mixed land uses, and a stronger sense of community).

90 David Harvey, The Spaces of Utopia, in Between Law and Culture: RELocating LEgai. STUDiEs 105 (David Theo Goldberg et al. eds., 2001).

91 James H. Kunstler, Home From Nowhere: REMAKInG OUR Everyday WORLD FOR TIIE 21ST CENTURY 194 (1996).

${ }^{2}$ See HARVEY, supra note 90 at 105 (suggesting that community can serve as a barrier to social change).
} 
collective memory out of which new Urbanism has been created is contested and contingent.

To summarize, urban land use planning in the United States began as a mostly private system of land use regulation which, after the turn of the nineteenth century, ultimately evolved into widespread zoning schemes that all but replaced private land use schemes as a means of planning. Formbased code, a principal tool of New Urbanism, represents the next step in the evolution of land use planning; like zoning, this tool comes at time of massive social and economic change in the American urban environments. In such a context, the word community becomes even more a contested notion. For this reason, one of the most noteworthy features of the form based code, the community consultative process via the charrette, becomes a subject for significant critique.

\section{THE ChARRETTE AND THE NATURE OF THE "COMMUNITY" IN THE Process of DEVEloping THE Form-BASEd Code}

In writing about the communal nature of the city and the development of neighborhoods, Jane Jacobs expressed skepticism about the notion held by traditional planners that there was a sufficient commonality between people living in the same geographical area of a city so as to assume them to be allies for purposes of creating and maintaining successful cities. ${ }^{93}$ She suggested, for example, that the several thousand residents of a particular section of a large city have no "innate degree of natural cross connection" "94 - such as that presumed by traditional planners and therefore city planning which seeks to foster the growth of neighborhoods can have only limited success. ${ }^{95}$ These observations remain true. The differences between and among the residents in any particular section of a city remain one of the biggest challenges to promoting communal interactions or obtaining communal consensus. As Jacobs understood, there is not necessarily a pre-existing body of persons who make up the community. Instead, there are often interest groups and these interest groups may serve as proxies for the community as a whole even while actively excluding some elements of the community. ${ }^{96}$ Such groups

\footnotetext{
${ }^{93}$ See Jane JaCobs, The DeATH AND LifE of GREAT American Cities, at 11416 (pointing out that people in a particular geographical area often will have a different vision of an "ideal" city).

${ }_{94} I d$. at 115 .

${ }^{95} \mathrm{Id}$.

96 See David a Hardcasti., Community Practice: Theorifs and SkII.s FOR SOCIAL WORKERS (PATRICE R. POWERS AND SIANLEY WENCOUR) 112 (1997)
} 
may wield power in ways that corrupt or deform processes of group decision-making. Moreover, the decision to vest individuals in a community with a significant amount of neighborhood design autonomy may be politically inspired. It is for these reasons that the role of the charrette in implementing design-based code should be the subject of some concern.

\section{A. The Multiple Strands of "Community" and the Charrette as a Tool of an Entrenched Elite}

As some experts on form-based code have observed about traditional planning tools, there are assumptions, sometimes unstated, made about a wide set of communal and societal relations such as gender, racial, economic, and familial interactions. ${ }^{97}$ These assumptions become embedded as norms in the framework of such planning processes and systems, and shift the balance of power resulting in the domination and marginalization of some groups. A shift to form-based code's charrette process comprised of "rational" face-to-face meetings has the risk of replicating existing power dynamics, since the dominant are often better equipped to manage and control such processes. Because form-based code focuses on localized developments and the character of those developments, it potentially allows empowered elites not only to retain control of the planning process but to custom-tailor their own neighborhoods without concern for the needs of the broader municipality. In the absence of a strong central municipal government to manage community design with an eye towards broad societal concerns such as environmental impact, the charrette could become a means of further disempowering the already disenfranchised. ${ }^{98}$

(citing a community's decision to exclude the homeless as an example of democratic decision-making that results in the exclusion of certain groups.); see also FLOYD Hunter, COMMUNiTy POWER STRUCTURE: A STUdy OF DECISION MAKERS 259 (University of North Carolina Press)(1953) (arguing that it would be "naïve" to assume that club or community groupings will "open their membership to many elements in the community, including Negro citizens, labor, women and others"). The latter observation often proves as true now as it did in the middle of the last century.

${ }^{97}$ See SANDERCOCK, supra note 70 (arguing that planning history must be reconceptualized by using gender and race as categories of analysis).

98 A number of scholars have written about the way that privilege is often maintained in legal and law-like systems in the face of "delegalizing" or "deformalizing" processes. See, e.g., Richard Abel, Delegalization: A Critical Review of Its Ideology, Manifestations and Social Consequences, in Alternative Legal Forums and Alternatives to Law 27 (Erhard Blankenburg et al. eds., 1980).; Marc Galanter, Why the Haves Come 
The charrette process used in form-based code schemes is an example of what several planning scholars call "collaborative planning" or "communicative planning." Such processes rely upon what has been called "inclusive argumentation." One of the significant concerns of turning over a neighborhood to the form-based code process is whether such a process can or will take into account broader concerns such as environmental impact and infrastructure needs as well as issues of social equity and differential access to power. It has been observed, for example, that planning and zoning are not disconnected from political and social context, notwithstanding the effusions of "supply side" planning theorists who view such endeavors as essentially unproblematic. ${ }^{99}$

In the area of planning, there has long been insufficient attention to, and a deep ambivalence about, what is in many cases a clear cut differential in power or access to power. ${ }^{100}$ Hence, what is needed is a focus on what has been described as the "dark side" of traditional land use planning. ${ }^{101}$ This would mean, for example, considering "demand side" planning concerns, acknowledging and even engaging the disorder of actual planning and design outcomes, and the lived experiences of participants in such processes. There is, in contrast to the utopian, apolitical and idealized history of zoning and planning, a "noir" history, one which addresses the very real fact that planning has been, and continues to be in a number of cases, a tool of social oppression. ${ }^{102}$ This is frequently true because planning projects are driven by elites.

Out Ahead, 9 LAW \& SoC'y RFv. 95 (1974).

${ }^{99}$ FREESTONE, supra note 87 at 2.

100 Bent Flyvbjerg, Bringing Power to Planning Research: One RESEARCHER'S STORY, IN PlanNING IN A GLOBAL ERA 117 (Andy Thornley \& Yvonne Rydin eds., 2003) (describing the ambivalence to the importance of power in city planning).

${ }^{101}$ See Oren Yiftachel, Planning and Social Control: Exploring the "Dark Side", 12 J. PLAN. LITER ATURE 395, 396 (1998) (exploring the links between planning and state mechanisms of social control and oppression).

${ }^{102}$ As Yiftachel writes:

Most accounts of planning neglect to explain its frequent application for purposes of (deliberate) social control, as expressed in the oppression of peripheral groups. This is not to claim, of course, that planning is inherently regressive, but rather that its well-documented progressive potential should also be understood as having a more sinister accompanying 'dark side'. This dark side is particularly evident when planning is used by 'ethnic states' as part of their territorial policies, but 


\section{B. Fears of "Responsibilitization" and the Establishment of "Government at a Distance"}

Control by elites remains a problem in the case of a relatively new planning or regulatory tool such as form-based code. This is true because form-based code relies upon what has been called "responsibilitization"-the politically inspired imposition of autonomy upon those who had previously lacked such autonomy. ${ }^{103}$ Responsibilitization is seen in a number of areas, such as criminal enforcement via third party policing. ${ }^{104}$ It is part of a broader societal move away from Keynesian welfarism, ${ }^{105}$ - exemplified by

is also rife in western societies governed by formal democratic principles

of governance.

Id. at 395 .

103 See Janf. I. Coldins, Transnational, Labor Process and Gender RELATIONS: WOMEN IN FRUIT AND VEgETABLE PRODUCTION IN CHILE, BRAZIL AND MLXICO, IN PLRSPLCIIVls ON LAS AMĹRICAS: A RLADLR IN CUL'TURL, HISTORY, AND REPRESENTATION 160, 167 (Félix V. Rodríguez \& Matthew C Guttmann eds., 2003) (describing how "responsibilitization" has been used to shift decision-making and quality control to certain jobs).

104 LORRAine Mazerolle \& JANET RANSLEy, ThiRd PARTy POlicing 52 (2006). One frequently discussed form of responsibilitzation is third party policing. Third party policing is a style of policing involving many different persons or entities, such as private individuals or community groups, who exercise regulatory control. Id. at 2. Those involved may be willing or unwilling partners. $I d$. This is because the regulatory framework for such policing schemes includes mechanisms for the police to coerce participation or threaten civil or administrative sanctions for failure to participate. Kristian Williams, OUR Enemies In Blue: Police ANd PoWER In AMERICA 241-242 (2004). Continued crime after the implementation of this form of responsibilitization is often seen not as a failure of police but of the citizens who are made "partners" in third party policing. Id. In like manner, turning planning processes over to citizens, particularly those ill-equipped to manage such processes, may easily make citizens rather than government liable for planning failure.

${ }^{105}$ John Maynard Keynes was a social democrat who greatly influenced the formation of the welfare state after World War II as a direct affront to the economic liberalism that had flourished in the United States from the $1800 \mathrm{~s}$ until the early $1900 \mathrm{~s}$. Keynes's theories challenged the notion that economic liberalism, characterized by an unrestrained market, little government intervention in economic and social policy, and reliance upon individual private initiative, was best for the success of a nation. See, e.g, Sanford F. SCHRam, Praxis for thF, PoOr: Piven and Ci,oward and the, Future OF SOClal SCIENCE IN SOCIAL WELFARE 213 (2002). 
provision of services - and towards neo-liberal governance. ${ }^{106}$ The key feature of neo-liberal governance is the way in which individuals are incorporated into the process of managing their own lives as an enterprise via rational decision making. ${ }^{107}$ Neo-liberalism engages in the "valorization of the self-actualized subject." 108 This goal is typically achieved by two dominant modes of neoliberal practice: "government at a distance," wherein there is top-down reform of state apparatuses based on a market model. ${ }^{109}$ This reform generally takes the form of deregulation and privatization. ${ }^{10}$ The second takes a bottom-down approach which centers on building the "social capital" of the individual. ${ }^{111}$

The government at a distance model tries to improve government by collaborating with private actors and bringing market behavioral practices and discursive practices into the government. One example is the many public school boards who have renamed the superintendent position "CEO," 112 ostensibly to cultivate in the public eye the idea that a particular school system is "competitive." The social capital model operates at the level of the individual and civil society and encourages individuals, and the communities to which they belong, to be responsible, autonomous and ultimately self-governing. ${ }^{113}$ Through such programs neo-liberal government can achieve its objectives all while reducing its commitment to formal governance and resource provision. ${ }^{14}$ Form-based code closely resembles this social capital model and thus may be located in the arsenal of neo-liberal weaponry for revising government.

Form-based code, like many other neoliberal tools, typically implies the resituating of the boundaries between public responsibility and private

${ }^{106} I d$. at 23.

${ }^{107}$ Alizon Draper \& Judith Green, Food Safety and Consumerism: Constructions of Choice and Risk, in WELFARE OF FOOD: RIGHTS AND RESPONSIBILITIES IN A CHANGING WORLD 54, 66 (Elizabeth Dowler \& Catherine Jones Finer eds., 2003).

108 Sean Patrick Eudaily, The Present Politics of the Past: Indigenous Legal Activism and Resistance to (Neo)Liberal Governmentality 52 (2004), citing Mitchell Dean, Governmentality: Power and Rule in Modern Society 155 (1999).

${ }^{109} I d$. at 52 .

${ }^{110}$ Id., citing Bradford at 204.

${ }^{111}$ Id., citing Dean, supra note 108 at 152.

112 A number of large urban school districts have renamed their school superintendents CEOs (Chief Executive Officers), apparently in an effort to bring some of the virtues of private industry into what are often dysfunctional public school systems. See e.g. Virgini P. COLlier ET AL., TIIE SUPERINTENDENT AS CEO: STANDARDSBASED PERFORMANCE 1-3 (2005).

${ }^{113}$ Eudaily, supra note 108 at 53.

${ }^{114} I d$. 
duty, the citizen as client and customer in a marketplace responsible for their own happiness, success, and health. ${ }^{115}$ In such regimes, elites with education, money, and experience in formal processes are often able to take charge of the design process. This often results in the same sort of outcomes that urban renewal undertaken under a broad neoliberal scheme wrought: fewer communities of color, fewer poor people, and fewer services for the members of those communities who remained after the implementation of such processes. ${ }^{116}$

Traditional zoning may also be viewed as broadly democratic and communitarian. Zoning and planning schemes emphasize health, safety, and welfare; they develop through a political process that is theoretically accessible to all, and broadly applicable to a municipality. In the seventyplus years since zoning schemes have been in use, this view seems to have won ideologically. This is in part because in many large urban areas the historically disenfranchised, such as racial minorities, have taken control of the civic governments responsible for zoning and planning. It is just now, however, that zoning is becoming suspect and disfavored in some circles. Form-based code has the potential to allow those without official political power in a city to control their own small fiefdom without effecting widespread changes to the benefit of all. A case in point is the city of New Orleans in the aftermath of Hurricane Katrina.

\section{The Form-Based Code Process and the Case of Hurricane Katrina}

On August 29, 2005, Hurricane Katrina, a massive category three ${ }^{17}$ storm, hit New Orleans, Louisiana and the surrounding Gulf Coast area, causing a level of destruction not experienced in the area in decades. ${ }^{118}$

115 Peter Brand \& Michael J. Thomas, Urban EnVironmentalism 94 (2005).

${ }^{116}$ Rachel Weber, Extracting Value From the City: Neoliberalism and Urban Development, in SPACES OF NEOLIBERALISM 172, 183-187 (Neil Brenner \& Nick Theodore eds., 2003).

117 The Saffir-Simpson Hurricane Scale measures hurricane intensity. The scale ranges from 1 to 5 , with 1 having the least intensity and wind speeds between 74 and 95 miles per hour, and 5 being the most intense with wind speeds greater than or exceeding 156 miles per hour. Hurricane Katrina was a Category 3 storm . For a discussion of the development and use of the Saffir-Simpson Hurricane Scale, see JUDITH A. HOWARD \& ERNEST ZeBrowski, CATEGORY 5: THE STORY OF CAMILlE, LESSONS UNLEARNED FROM AMERIC $\Lambda$ 'S MOST VIOLENT HURRICANE 21 1-235 (2005).

${ }^{118}$ Prior to Katrina, the last storm to cause significant damage to New Orleans was Hurricane Betsy in 1965. However, no storm other than Katrina has wielded such destructive force in the United States since the 1928 Okeechobee hurricane, also known 
Approximately eighty percent of New Orleans was flooded, with some of the most severe damage occurring in the Lower Ninth Ward, Central City, and the Seventh Ward, all areas heavily populated by AfricanAmericans. ${ }^{119}$ In the period since Hurricane Katrina, poor black victims have been the slowest to return to New Orleans. ${ }^{120}$ There are a number of the reasons for inability of poor black Katrina victims to return to New Orleans. ${ }^{21}$ Perhaps chief among them is the absence of habitable dwellings, which has been a problem exacerbated by the failure of local authorities to take full charge of the planning process and thereby create a framework for rebuilding.

Recently New Orleans officials chose to forego a traditional comprehensive Euclidean zoning scheme in favor of a planning process that will delegate responsibility to fifteen planning teams guided by groups of residents from various parts of New Orleans. ${ }^{122}$ Although the grand scheme calls for all of the individual neighborhood plans to be incorporated into a single master plan at some point, thus far there are no comprehensive guidelines being promulgated for the design of the neighborhoods. In the absence of new, broadly applicable standards, residents are free to rebuild in exactly the same manner that caused many properties to sustain serious

as the San Felipe hurricane, which killed over 3,000 people in Florida and Puerto Rico, and many hundreds more on the Caribbean island of Guadeloupe. The Okeechobee hurricane caused over 800 million dollars in damage in today's dollars. See generally ELIOT KLEINBERG, BLACK CloUd: TIIE GREAT FlORID $\Lambda$ STORM OF 1928 (2003).

119 New Orleans is divided into 17 wards. The Ninth ward, located in the easternmost downriver portion of the city, is the largest of these wards. According to the Urban Institute, the population of the flooded neighborhoods was seventy-five percent African American. SUSAN J. POPKIN ET $\Lambda$ L., TIIE URBAN INSTITUTE, REBUILding AfFordable Housing in NeW OrLEans: The Challenge of Creating InClusive COMMUNiTIES (2006). The Lower Ninth Ward - one of the hardest hit - was, prior to Hurricane Katrina, approximately 97 percent black. DOUGLAS BRINKLEY, THE GREAT

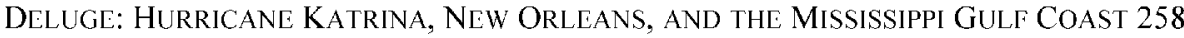
(2006).

${ }^{120}$ William H. Frey \& Audrey Singer, Katrina and Rita Impacts on Gulf Coast Populations: First Census Findings, in THL BROOKINGS INSTITUTION: CITILS AND SUBURBS, available at http://www.brookings.edu/metro/pubs/20060607_hurricanes.htm. (last visited November 28, 2006). Full report on file with the author.

${ }^{121}$ For a fuller discussion of the housing-related problems of poor blacks in New Orleans in the Aftermath of Hurricane Katrina, see Lolita Buckner Inniss, A Domestic Right of Return? Race, Rights and Residency in New Orleans in the Aftermath of Hurricane Katrina, 27 B.C. THIRD WORLD L.J. 325 (2007).

${ }^{122}$ Nicolai Ourousoff, In New Orleans, Each Resident is Master of the Plan to Rebuild, N.Y. Times, August 8, 2006, at B1. 
and in some cases irremediable damage. ${ }^{123}$ Groups of residents, while ostensibly empowered to affect their own neighborhoods or their own houses, are not empowered to undertake the sort of broad structural and environmental remediation needed to avoid future disasters. ${ }^{124}$

Moreover, even if such consultations were able to reflect the views and the needs of the broader constituency, there is some concern that residents would avoid doing so in lieu of promoting their own parochial concerns based on commonalities like race, class, and economic status. ${ }^{125}$ Indeed, in the context of civic planning, community consultations are rarely able to capture the views of the most disempowered groups. ${ }^{126}$ This last point is one of particular concern in New Orleans. New Orleans was a hotbed of race and class divisions before the hurricane and certainly remains so afterward. Moreover, New Orleans city planning processes, like those in many United States Southern cities, had long been dominated by elites; this was due in part to those cities' antebellum social structures. ${ }^{127}$ It has been asserted that one of the principal reasons that post-Hurricane New Orleans opted for the community-guided plan was that efforts to develop a comprehensive citywide plan were challenged for failing to take into account racial and economic diversity. ${ }^{128}$ By delegating the responsibility for planning to the resident-led design teams, the city was effectively able to abdicate the broader responsibility that it would have had under a traditional Euclidean scheme. This appears to inhere especially to the disadvantage of poor black New Orleans residents.

Though a number of areas sustained significant damage in Hurricane Katrina and in Hurricane Rita, the storm that came less than a month later, some of the greatest damage occurred in low-lying predominantly black areas such as the Lower Ninth Ward and the Seventh Ward. ${ }^{129}$ These areas also had the highest rates of poverty and the fewest resources in general. ${ }^{130}$ Many of the residents are little equipped to undertake the necessary

${ }^{123} \mathrm{Id}$.

${ }^{124} \mathrm{Id}$.

125 Ourousoff, supra note 122.

126 Friedmann, supra note 68 at 101.

127 David R. Goldfield, Planning For Urban Growth in the Old South, in TIIE Rise OF MODERN URBAN PlanNING, 1800-1914 11, 12-15 (Anthony Sutcliffe ed., 1980).

${ }^{128}$ Ourasoff, supra note 122.

${ }^{129}$ See Id. note 117. The Seventh Ward, located near downtown New Orleans extending from Esplanade Avenue to Elysian Fields, is one of the lesser known areas of New Orleans, yet one of the hardest hit by the flooding in the aftermath of Hurricane Katrina. See RoD AMIS, Katrina AND thF, LOST City OF NFW ORI,EANS 64 (2005).

${ }^{130}$ ROD AMIS, KATRINA AND THE LOSI CITY OH NEW ORLEANS 64 (2005). 
measures to plan for the rebuilding of their neighborhoods. Already it has been observed that residents in affluent neighborhoods have been the best organized and thus best able to take advantage of the form-based process. ${ }^{131}$ This suggests that the neighborhoods that suffered disproportionately in Hurricane Katrina because of location and infrastructure disadvantages may risk having those same disadvantages carried over in the form-based code process. Yet, because such processes are largely self-regulated, there is no central authority that residents could rely upon to provide relief.

\section{CONCLUSION}

There is no doubt that form-based code may hold promise for the revitalization of old cities and for the creation of new ones. Jane Jacobs, a critic of traditional planning and zoning schemes, announced at the outset of The Death and Life of Great American Cities that the book was intended as "an attack on current city planning and rebuilding." 132 Writing in 1961, Jacobs was speaking of the highly formulaic Euclidean-based zoning that was at the heart the planning schemes in United States cities, and of the explicit goals of such schemes were manifold - slum clearance followed by the creation of more middle and upper income housing areas, and cultural, civic, and commercial centers to serve the new populations. ${ }^{133}$ Such explicit civic planning, wrote Jacobs, often failed. ${ }^{134}$ It failed to take into account that there was order underlying even the seeming unplanned disorder of successful cities, order that resulted from "an intricate and close grained diversity of uses." 135 Form based code is a New Urbanist tool whose goal is to reinstate form and utility based cityscapes of the prezoning period of American cities.

Form-based code, however, attempts to reproduce traditional city diversity in all of its meanings by moving away from a formal rational legal system $^{136}$ of traditional Euclidean zoning and planning and towards a more substantively rational law ${ }^{137}$ growing out of self-government. Form-based

\footnotetext{
${ }^{131}$ Ourosoff, supra note 122.

132 Jacobs, supra note 4 at 1.

${ }^{133} \mathrm{Id}$.

${ }^{134} \mathrm{Id}$.

${ }^{135} I d$. at 14.
}

${ }^{136}$ Formal rationality refers to a system of law that creates and applies a body of universal rules to a particular area of endeavor. See Gunther Teubner, Substantive and Reflexive Elements in Modern Law, 17 LAW AND SOC'Y REV. 239, 240 (1983), citing MAX WfBER ON LAW AND ECONOMY IN SOCIETY 39, 61 (Max Rheinstein ed.) (1954).

137 Substantively rational law achieves a specific purpose or goal. Id. at 240 , 
code, however, is not "un-zoning" or "un-planning." Instead, it is alternate zoning or planning by persons who in many cases may not be accountable to the larger community. As such, it offers a flawed answer to the problems of a more formal, centralized zoning and planning regime. As Arthur Stinchcombe writes in When Formality Works, ${ }^{138}$ there is an increased assault upon formality in legal and social systems because of misconceptions about how formality functions. ${ }^{139}$ Formality in the context of traditional zoning is not the source of ill-functioning cities, social exclusion or the skewed power dynamics that are often seen in American cities. Rather, these ills, and especially the creation and maintenance of privilege, are accomplished through myriad means. What New Urbanists fail to acknowledge is that form-based code, all while promoting an ethic of neighborhood self-government, may itself be co-opted as a tool for perpetuating disadvantage.

citing Weber, supra note 136 at 63, 303.

${ }^{138}$ ARTHUR L. STINCHCOMBE, WhEN Formality WORKS: AUTHORITY AND ABSTRACTION IN LAW AND ORGANIZATIONS (2001).

${ }^{139} I d$. at 2. 
